\title{
HUBUNGAN TINGKAT PENGETAHUAN DAN SIKAP DALAM MENGATASI DISMENOREA PRIMER PADA REMAJA
}

\section{RELATIONSHIP ON KNOWLEDGE AND ATTITUDE LEVELS IN OVERCOMING PRIMARY DISMENOREA IN TEENAGER}

\author{
Luluk Eka Meylawati ${ }^{1}$, Fitri Anggraeni ${ }^{2}$ \\ Akademi Keperawatan RSP TNI AU ${ }^{1,2}$ \\ email : lulukmeylawati17@gmail.com, fitri.anggraeni.0686@gmail.com
}

\begin{abstract}
ABSTRAK
Pada saat terjadi menstruasi, remaja seringkali mengalami nyeri haid yang dapat mengakibatkan terganggunya aktivitas bahkan sampai terjadi gangguan pencernaan. Untuk mengatasi nyeri haid tersebut, sikap dan tindakannya sesuai dengan pengetahuan yang dimilikinya. Desain yang digunakan pada penelitian ini bersifat deskriptif dengan metode cross sectional dengan teknik Non Probability Sampling dengan metode dengan teknik total sampling, analisa dengan menggunakan uji Chi Square diperoleh nilai $p=0,020$. Kesimpulannya adalah ada Hubungan Tingkat Pengetahuan dan Sikap dalam Mengatasi Dismenorea Primer Pada Remaja. Perawat diharapkan dapat melakukan pendidikan kesehatan dengan memberikan informasi serta penanganan tentang disminorea untuk meningkatkan pengetahuan remaja.
\end{abstract}

Kata Kunci: Disminorea, Pengetahuan, Sikap

\begin{abstract}
At the time of menstruation, adolescents often experience menstrual pain which can result in disruption of activities and even digestive disorders. To overcome the menstrual pain, attitudes and actions are in accordance with the knowledge they have. The design used in this study is descriptive with cross sectional method with Non Probability Sampling technique with total sampling technique, analysis using Chi Square test obtained $\mathrm{p}$ value $=0.020$. The conclusion is that there is a relationship between the level of knowledge and attitudes in overcoming primary dysmeKorrhea in adolescents. Nurses are expected to be able to provide health education by providing information and handling about dysmenorrhea to increase adolescent knowledge.
\end{abstract}

Keywords: Dysminorrhea, Knowledge, Attitude 


\section{PENDAHULUAN}

Menstruasi merupakan insiden yang krusial ketika masa remaja dan dapat mengakibatkan gangguan yang relatif berarti bagi wanita. Pada saat terjadi menstruasi, wanita seringkali mengalami nyeri haid atau yang disebut sebagai dismenorea ${ }^{1}$. Hal ini disebabkan oleh pengeluaran prostaglandin yang dapat mengakibatkan nyeri ketika menstruasi ${ }^{2}$.

Disminorea yang dirasakan oleh remaja dapat mengakibatkan terganggunya aktivitas bahkan sampai terjadi gangguan pencernaan dan mereka merasa bahwa dismminorea bukanlah merupakan suatu masalah dan akan hilang dengan sendirinya. Tanpa mereka sadari, disminorea bisa menjadi indikasi suatu penyakit contohnya endometriosis yang dapat mengakibakan sulitnya mendapat keturunan ${ }^{2}$.

Menurut World Health Organization (WHO), insiden dismenore relatif tinggi di seluruh dunia yaitu antara $16,8-81 \%$ dan terjadi pada dewasa muda. Sedangkan di Eropa angka kejadian tertinggi yaitu $94 \%$ terjadi di Finlandia dan angka kejadian yang terendah yaitu di Bulgaria sebanyak $8,8 \%$ dan banyak ditemukan pada usia remaja yaitu sekitar $20 \%$ - 90\% dan yang mengalami disminorea berat mencapai $15 \%$. Angka kejadian disminorea di Amerika Serikat sebesar 29\% - 44\% di usia 18 - 45 tahun dan menyebabkan banyak siswi tidak masuk sekolah $^{3}$.

Data tentang masalah dismenore pada remaja belum banyak didapatkan di Indonesia. Kecenderungan remaja untuk menganggap bahwa disminorea bukanlah suatu masalah dan juga tidak mau memeriksakan ke pelayanan kesehatan merupakan penyebab data tentang masalah disminorea tidak banyak diketahui. Dari hasil penelitian di Indonesia yang dilakukan oleh Pusat Informasi dan Konseling Kesehatan Reproduksi Remaja (PIK-KRR) pada tahun 2009 yaitu insiden dismenore terdiri dari $72,89 \%$ dismenore primer, $27,11 \%$ dismenore sekunder dan insiden dismenore berkisar $45-95 \%$ di kalangan wanita usia produktif ${ }^{4}$.

Beberapa penelitian yang dilakukan terhadap remaja Sekolah Menengah Pertama di Surakarta menunjukkan bahwa $87,7 \%$ mengalami dismenore, dengan skor kecemasan yang tinggi yaitu $47,8 \%$, serta sebanyak $41,2 \%$ tetap melakukan kegiatan seperti biasa meskipun saat terjadi dismenorea ${ }^{7}$. Penelitian lain yang dilakukan di Sekolah Menengah Pertama 3 Menado menunjukkan bahwa sebnyak 40,7\% mengalami dismenorea disertai dengan tanda penyerta. Meski demikian, sebanyak $82 \%$ remaja tidak melakukan tindakan apapun saat terjadi disminorea, dan kebanyakan dari remaja tersebut mendapatkan informasi dari teman-temannya dan bukan berasal dari tenaga kesehatan. Hal ini menggambarkan bahwa insiden dismenore pada remaja masih relatif tinggi. Pengetahuan tentang disminorea yang dimiliki oleh remaja akan mempengaruhi sikap yang diambil oleh remaja. Apabila para remaja mempunyai pengetahuan yang cukup terkait dengan disminorea, maka remaja tersebut akan bersikap secara positif. Begitupun sebaliknya, apabila pengetahuan yang dimiliki oleh para remaja kurang, maka akan timbul rasa cemas dan cenderung sikap negatif yang akan ditunjukkan ${ }^{4}$.

Gangguan disminorea dapat diatasi dengan menggunakan obat-obatan dan juga non farmakologis. Penganganan secara non farmakologis bisa dilakukan dengan cara latihan jasmani secara rutin, kompres hangat, istirahat dan relaksasi ${ }^{5,3}$. Tindakan yang diambil oleh seseorang tidak akan lepas dari pengetahuan yang telah dimilikinya sehingga akan berpengaruh pada pengambilan keputusan terhadap masalah yang sedang dihadapi ${ }^{6}$. Pengetahuan terkait dengan disminorea yang dimiliki oleh para remaja juga akan mempengaruhi sikap dalam mengatasi 
disminorea tanpa adanya penyakit penyerta. Sikap dalam mengatasi disminore dipengaruhi oleh pengetahuan yang dimiliki. Apabila remaja mempunyai pengetahuan yang cukup terkait disminorea, maka sikap yang diambil lebih ke arah yang lebih baik. Begitupun sebaliknya, apabila pengetahuan yang dimiliki oleh remaja kurang, maka sikap yang diambil lebih ke arah yang negatif ${ }^{7}$.

Studi pendahuluan yang telah dilakukan dengan melakukan wawancara dan pengisian kuesioner terkait dengan pengetahuan tentang disminorea kepada 48 responden yang ada di Akademi Keperawatan RSP TNI AU Jakarta tahun 2019/2020 pada bulan Juni diperoleh ada 24 mahasiswa yang mempunyai pengetahuan tentang disminorea namun belum mengetahui bagaimana cara menangani disminorea secara benar.

\section{METODE}

Penelitian ini menggunakan desain yang bersifat deskriptif dan metode cross sectional, dimana peneliti melakukan pengukuran variabel pada saat yang bersamaan yang tujuannya adalah untuk mengetahui "Hubungan Tingkat Pengetahuan dan Sikap dalam Mengatasi Dismenorea Primer Pada Remaja". Tempat penelitian yang dipilih adalah di Akper RSP TNI AU Jakarta.

Populasi dalam penelitian ini adalah semua mahasiswa Akademi Keperawatan RSP TNI AU Jakarta tingkat II angkatan 2018. Pengambilan sampel penelitian ini dilakukan secara nonprobability sampling dengan teknik total sampling dimana mengambil semua anggota populasi menjadi sampel. Jumlah sampel dalam penelitian ini adalah sebanyak 51 responden.

Instrumen dalam penelitian ini menggunakan kuesioner. Dimana kuesioner tentang tingkat pengetahuan terdiri dari 10 pertanyaan dalam bentuk pilihan ganda, dari masing-masing pertanyaan diberi skor 1 jika jawaban benar dan skor 0 jika jawaban salah dengan hasil uji validitas nilai signifikansi $<0,05$ dan hasil uji reliabilitas 0,807 (nilai cronbach alpha $>0,6$ ). kuesioner tentang sikap terdiri dari 10 pertanyaan dalam bentuk skala likert, dari masing-masing pertanyaan diberi skor 1 jika jawaban sangat tidak setuju (STS), skor 2 jika jawaban tidak setuju (TS), skor 3 jika jawaban setuju (S), dan skor 4 jika jawaban sangat setuju (SS) dengan hasil uji validitas nilai signifikansi $<0,05$ dan hasil uji reliabilitas 0,781 (nilai cronbach alpha > 0,6). Data yang didapat kemudian dianalisa melalui dua tahap yaitu analisa univariat dan analisa bivariat dengan menggunakan uji statistik chi square.

\section{HASIL}

Analisis univariat dilakukan terhadap tiap variabel penelitian dimana terdapat karakteristik responden (umur mahasiswi dan usia menarche), variabel dependen (dismenorea primer), dan variabel independen (tingkat pengetahuan dismenorea dan sikap).

Tabel 1

Distribusi Frekuensi Responden Berdasarkan Karakteristik Umur

\begin{tabular}{lll}
\hline & Jumlah & $\%$ \\
\hline Mean & 8,5 & 16,67 \\
Median & 7,5 & 14,7 \\
Min & 1 & \\
\hline
\end{tabular}

Berdasarkan tabel di atas, dapat diketahui jumlah responden tertinggi berada pada umur 21 tahun yaitu sebanyak masing 22 mahasiswi $(43,1 \%)$ dan terendah berada pada umur 22 dan 24 tahun yaitu sebanyak masing-masing 1 mahasiswi $(2,0 \%)$.

Tabel 2

Distribusi Frekuensi Responden Berdasarkan Karakteristik Umur Menarche

\begin{tabular}{lll}
\hline & Jumlah & $\%$ \\
\hline Mean & 7,29 & 14,29 \\
Median & 4 & 7,8 \\
Min & 1 & \\
Max & 20 & \\
\hline
\end{tabular}

Berdasarkan tabel di atas, dapat diketahui jumlah responden tertinggi usia menarche 12 
tahun yaitu sebanyak 20 mahasiswi $(39,2 \%)$ dan jumlah responden terendah pada usia menarche 16 dan 17 tahun yaitu sebanyak masing-masing 1 mahasiswi $(2,0 \%)$.

Tabel 3

Distribusi Frekuensi Responden Berdasarkan Sikap Mengatasi Disminorea

\begin{tabular}{lll}
\hline Variabel & Jumlah & $\%$ \\
\hline Sikap & & \\
mengatasi & & \\
disminorea & & \\
primer & & \\
Negatif & 29 & 56,9 \\
Positif & 22 & 43,9 \\
Jumlah & 51 & 100,0 \\
\hline
\end{tabular}

Berdasarkan tabel di atas terlihat bahwa sebagian besar responden memiliki sikap yang negatif yaitu sebanyak 29 mahasiswi $(56,9 \%)$ dan 22 mahasiswi $(43,9 \%)$ sikap yang positif.

Tabel 4

Distribusi Frekuensi Responden Berdasarkan Tingkat Pengetahuan Disminorea

\begin{tabular}{lcc}
\hline Variabel & Jumlah & $\%$ \\
\hline Tingkat & & \\
Pengetahuan & & \\
Disminorea & & \\
\hline Kurang & 21 & 41,2 \\
Cukup & 30 & 58,8 \\
Jumlah & 51 & 100,0 \\
\hline
\end{tabular}

Berdasarkan tabel di atas, terlihat bahwa sebagian besar responden memiliki tingkat pengetahuan yang cukup yaitu sebanyak 30 mahasiswi $(58,8 \%)$ dan 21 mahasiswi $(41,2 \%)$ tingkat pengetahuan yang kurang.

Tabel 5

Hubungan Sikap Mengatasi Dismenorea Primer terhadap Tingkat Pengetahuan Dismenorea

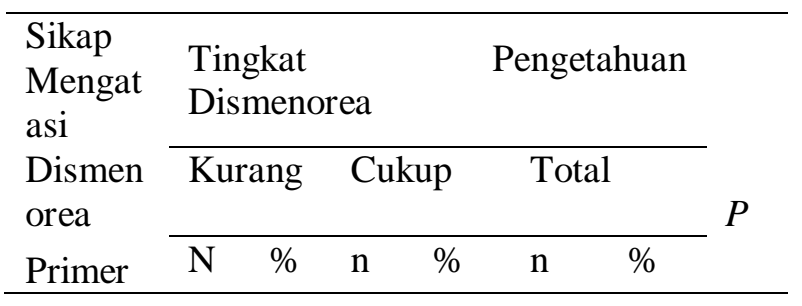

\begin{tabular}{lcllllll}
\hline Negatif & 16 & 31 & 13 & 25, & 29 & 56, & \\
& &, 4 & & 5, & & 9 & \\
Positif & 5 & 9, & 17 & 33, & 22 & 43, & 0, \\
& & 8 & & 3 & & 1 & 02 \\
& & & & & & & 0 \\
Total & 21 & 41 & 30 & 58, & 51 & 100 & \\
& &, 2 & & 8 & &, 0 & \\
\hline
\end{tabular}

Berdasarkan tabel diatas terlihat bahwa dari 51 mahasiswa terdapat 16 mahasiswi $(31,4 \%)$ yang Sikap Mengatasi Dismenorea Primer negatif dengan Tingkat Pengetahuan Dismenorea kurang dan 17 mahasiswi (33,3\%) dengan Sikap Mengatasi Dismenorea Primer yang positif dengan Tingkat Pengetahuan Dismenorea cukup. Berdasarkan uji statistik dengan uji chi square diperoleh nilai $p=0,020$. Dengan demikian $p<\alpha(0,05)$ sehingga "ada Hubungan Tingkat Pengetahuan dan Sikap dalam Mengatasi Dismenorea Primer Pada Remaja".

\section{PEMBAHASAN}

Seluruh responden adalah mahasiswa dengan rentang usia antara 19-24 tahun. Di usia remaja, terjadi banyak pertumbuhan baik dari segi fisik maupun psikis dan juga organ-organ reproduksi sehingga sering disebut sebagai periode hidup yang paling sehat ${ }^{8}$. Seiring dengan bertambahnya usia seseorang, maka akan diikuti dengan transformasi pada aspek fisik dan psikologis. Adapun pertumbuhan pada aspek fisik bisa dilihat dengan adanya perubahan ukuran maupun bentuk sebagai akibat dari fungsi organ yang semakin matang. Sedangkan pada pada aspek psikologis akan terjadi perubahan car aberpikirnya. Dengan adanya pertambahan usia, juga akan diikuti oleh semakin banyaknya pengalaman serta pengetahuan yang didapat sehingga akan mempengaruhi tingkat kematangan mental dan intelektual. Usia juga dapat mempengaruhi tingkat pengetahuan seseorang. Usia yang dewasa akan lebih dapat menerima informasi lebih baik daripada usia yang lebih muda .

Ada banyak faktor yang bisa mempengaruhi usia menarche. Hal ini sejalan dengan penelitian Larasati, N., S.F. Sintha., Puspareni, 
D.L.N tahun 2019 mengenai faktor-faktor yang berhubungan dengan kejadian menarche dini pada siswi Sekolah Menengah Pertama Setia Negara Depok tahun 2018 dimana hasilnya adalah ada hubungan antara status gizi, aktifitas fisik dan paparan media massa terhadap usia menarche. Penelitian yang dilakukan oleh Mutasya, UF., Edison., Hasyim, H. 2016 tentang faktor-faktor yang berhubungan dengan usia menarche siswi Sekolah Menengah Pertama Adabiah dengan hasil penelitian yang menunjukkan bahwa ada hubungan yang bermakna antara tingkat pendapatan per kapita dan status gizi terhadap usia menarche, sedangkan tingkat pendidikan orang tua dan paparan media massa tidak ada hubungan yang bermakna dengan usia menarche.

Sikap dalam menangani masalah disminorea dari responden dalam penelitian ini lebih banyak menunjukkan hasil yang negatif. Sikap yang ditunjukan oleh responden sesuai dengan pemahamanan yang dimilikinya sehingga akan berpengaruh terhadap keputusan atau tindakan yang diambil dalam menghadapi suatu masalah $^{7}$. Sikap seseorang dalam mengatasi disminorea bisa dipengaruhi oleh banyak hal antara lain yaitu wawasan yang dimilikinya, informasi yang didapat dari orang terdekat, media komunikasi baik itu cetak maupun eletronik, tempat dia menuntut ilmu baik formal maupun agama. Sikap akan terbentuk dengan adanya peristiwa yang kita alami secara pribadi apalagi melibatkan hal -hal yang sangat emosional. Informasi yang didapatkan dari orang yang kita anggap penting biasanya akan mempengaruhi sikap kita dalam mengatasi masalah secara tidak langsung. Sikap seseorang juga bisa dipengaruhi oleh adanya informasi dari media komunikasi baik cetak ataupun eletronik. Tempat seseorang dalam menuntut ilmu baik formal maupun agama juga dapat membuat kepribadaian yang menempatkan dasar definisi dan konsep moral ${ }^{10}$.

Dalam penelitian ini terdapat responden dengan tingkat pengetahuan yang cukup yaitu sebanyak 30 mahasiswi $(58,8 \%)$ dan 21 mahasiswi
(41,2\%) dengan tingkat pengetahuan yang masih kurang. Hal ini sejalan dengan penelitian yang dilakukan Salamah, U. (2019) diperoleh jumlah responden terbanyak yang memiliki pengetahuan baik sebanyak 67 orang $(77,9 \%)$. Informasi yang didapat oleh remaja akan berpengaruh pada pengetahuan yang dimiliki dan juga oleh karena tingkat pendidikannya. Peristiwa yang terjadi secara pribadi di masamasa sebelumnya juga dapat menjadi sumber pengetahuan yang bersifat informal ${ }^{7}$. Tingkat pengetahuan responden juga dipengaruhi oleh usia, yaitu semakin dewasa usianya maka kemampuan berfikirnya pun akan lebih baik ${ }^{10}$. Hal lain yang terkait dengan pemahaman responden tentang disminorea dikarenakan remaja yang menjadi subyek penelitian mengalami dismenorea pada siklus haidnya, sehingga lebih memahami gejala yang dialami pada saat dismenorea.

Berdasarkan uji statistik dengan uji chi square diperoleh nilai $p=0,020$. Dengan demikian $p<$ $\alpha(0,05)$ sehingga ada Hubungan Tingkat Pengetahuan dan Sikap dalam Mengatasi Dismenorea Primer Pada Remaja. Sikap yang ditunjukkan oleh responden dalam penelitian ini belum tentu sama dengan pengetahuan yang dimilikinya dikarenakan sikap tidak hanya dipengaruhi oleh pengetahuan, akan tetapi dapat dipengaruhi oleh banyak hal antara lain yaitu persitiwa yang pernah dialami oleh seseorang, informasi yang diberikan oleh orang terdekat, media komunikasi serta bisa dari tempat responden menuntut ilmu baik secara formal maupun agama. Jadi, pengetahuan yang baik belum tentu memiliki kepercayaan terhadap penanganan dismenorea primer baik pula. Terbentuknya sikap yang didasari oleh pengetahuan, kesadaran,dan sikap positif, maka sikap tersebut akan bersifat langgeng (long lasting $)^{7}$. Seseorang bebas mengambil keputusan untuk menangani masalah yang dia miliki dalam hal penanganan untuk disminorea. Keterbatasan dari penelitian ini adalah dikarenakan adanya pandemi Covid-19 sehingga keterbatasan dalam pengambilan 
sampel dan tempat penelitian yang terbatas sehingga tingkat kesalahannya semakin besar.

\section{KESIMPULAN}

Berdasarkan hasil penelitian yang dilakukan, dapat ditarik kesimpulan yaitu ada Hubungan Tingkat Pengetahuan dan Sikap dalam Mengatasi Dismenorea Primer Pada Remaja.

\section{SARAN}

Melanjutkan penelitian ini dengan lebih memperbanyak sampel serta tempat penelitian dan menggunakan variabel independen yang lain.

\section{DAFTAR PUSTAKA}

1. Saputri, FI. 2017, Pengaruh Peer Education Terhadap Sikap Menghadapi Kejadian Dismenore Pada Remaja Putri Di Pondok Pesantren Islamic Centre BinbazYogyakarta. Skripsi. Program Studi Diploma IV Kebidanan Poltekkes Kemenkes Yogyakarta.

2. Wiknjosastro, H., Saifuddin, A. B., Rachimhadhi, T. 2014. Ilmu Kebidanan. Edisi IV. Cetakan ke-4. Jakarta: Bina Pustaka Sarwono Prawirohardjo.

3. Silviani, Y. E., Karaman, B., \& Septiana, P. (2019). Pengaruh Teknik Relaksasi Nafas Terhadap Dismenorea. Hasanuddin Journal of Midwifery, 1(1), 30-37.

4. Saputri, FI. 2017, Pengaruh Peer Education Terhadap Sikap Menghadapi Kejadian Dismenore Pada Remaja Putri Di Pondok Pesantren Islamic Centre BinbazYogyakarta. Skripsi. Program Studi
Diploma IV Kebidanan Poltekkes Kemenkes Yogyakarta.

5. Anjarwati, S. 2012. Pengaruh Pemberian Jus Wortel Terhadap Penurunan Derajat Nyeri Dismenore Pada Mahasiswa Diii Kebidanan Di Stikes 'Aisyiyah Yogyakarta (Doctoral dissertation, Universitas' Aisyiyah Yogyakarta).

6. Achmadi, UF. 2013. Kesehatan Masyarakat: Teori dan Aplikasi, Jakarta: Rajawali Pers, 2013

7. Rahmawati, Tatik. 2016. Hubungan Tingkat Pengetahuan Dismenorea Mahasiswi Pendidikan Biologi Uin Walisongo Semarang Terhadap Sikap Mengatasi Dismenorea Primer. Skripsi. Pendidikan Biologi Fakultas Sains Dan Teknologi Universitas Islam Negeri Walisongo Semarang

8. Kemenkes RI. 2018. Menkes: Remaja Indonesia Harus Sehat. https://www.kemkes.go.id/article/view /18051600001/menkes-remajaindonesia-harus-sehat.html

9. Yeni, PSI. 2015. Faktor-Faktor Yang Berhubungan Dengan Pengetahuan Penggunaan Obat Generik Pada Masyarakat Di Wilayah Kerja Puskesmas Padang Panyang Kabupaten Nagan Raya Tahun 2015. Skripsi. Program Studi Ilmu Kesehatan Masyarakat Fakultas Kesehatan Masyarakat Universitas Teuku Umar..

10. Wawan, A dan Dewi M. 2010. Teori dan Pengetahuan, Sikap dan Perilaku manusia, Yogyakarta: Nuha Medika. 